\title{
INSTITUTIONAL PROBLEMS OF REGIONAL DEVELOPMENT IN RUSSIA
}

\author{
Natalia M. Syssoeva \\ Department of Regional Economic and Social Problems, Irkutsk Scientific Centre of Siberian Branch RAS, \\ Irkutsk, Russia \\ Manuscript received May 13, 2010 \\ Revised June 6, 2010
}

SyssOEvA N.M., Institutional problems of regional development in Russia. Quaestiones Geographicae 29(2), Adam Mickiewicz University Press, Poznań 2010, pp. 19-25, 1 Fig., 1 Table. ISBN 978-83-232-2168-5. ISSN 0137-477X. DOI 10.2478/v10117-010-0011-8.

\begin{abstract}
The paper presents problems of spatial policy in Russia related to the formation of institutional conditions for regional development. Development institutions are characterised in terms of three functional groups. Distributive institutions reallocate funds between regions and they are the main subject of research on development factors. Problems of the redistribution sphere include losses of regions and municipalities in rental payments and household incomes. Transformational institutions contribute to the transformation of income into investment, and their effectiveness depends upon the quality of human capital and forms of relationships in local and regional communities. Organising institutions are usually formed by the state to arrange and stimulate the implementation of measures determined by the state regional development policy. The programme of economic and social development of Siberia is analysed as an example of institutional framework construction. The role of informal norms in institutional environment development is stressed.
\end{abstract}

KEYWORDS: regional development, institutional environment, distribution and transformation of incomes, regions and municipalities

Natalia M. Syssoeva, Department of Regional Economic and Social Problems, Irkutsk Scientific Centre of Siberian Branch RAS, ul. Lermontova, 134, 664033 Irkutsk, Russia; e-mail: syssoeva@oresp.irk.ru

\section{Introduction}

Russian regional policy has developed against the background of the Soviet period with its active pioneering of land space and the construction of new industrial bases in the east and south of the USSR before and after World War II. But these achievements were accompanied by problems of stagnation and depression in regions beyond the state's priority. During the first decade of the post-Soviet period the state tried to work out the tools for regulation of regional development: budgetary relations, state financing of regional programmes and investment projects, and arrangement of federal orders. But the aims of the state regional programmes had not been accomplished and the main problems of a spatial character, namely disintegration of economic space and acceleration of interregional differences, became stronger (Table 1).

On the one hand, an institutional background offered in programmes of the first decade could not give an appropriate effect; on the other hand, although long-term problems were identified, no concept for their solution was worked out. The problems of regional development in Russia are 
TABLE 1. SELECTED INDICATORS OF INTERREGIONAL DIFFERENCES AND THEIR DYNAMICS

\begin{tabular}{|l|c|c|c|}
\hline & $\mathbf{1 9 9 5}$ & $\mathbf{2 0 0 0}$ & $\mathbf{2 0 0 6}$ \\
\hline $\begin{array}{l}\text { Gross regional product } \\
\text { per capita }\end{array}$ & & & \\
\hline max/min (times) & 20 & 26.5 & 44.8 \\
\hline max/average (times) & 3.41 & 4.48 & 5.0 \\
\hline $\begin{array}{l}\text { Number of regions with GRP p.c. larger } \\
\text { than average one }\end{array}$ & 25 & 17 & 16 \\
\hline Capital investments per capita & & & 186.7 \\
\hline max/min (times) & 49 & 180 & 36 \\
\hline max/average (times) & 15 & 21 & \\
\hline
\end{tabular}

Source: Russian Statistical Yearbook, 2008.

largely of an institutional nature, but it is not adequately reflected in the scientific literature.

In Russian economic geography the institutional approach is developed much less than in Poland and other countries with transitional economies, and is in the process of notion system formation. Attention is paid to specific geographical institutions, among which basic concepts of economic geography are listed, for example, territorial organisation of the economy and an economic region (Druzhinin \& Shuvalov 2004; Inshakov \& Frolov 2007). According to Martin (2000), these concepts should refer to "institutional arrangements", or institutionally determined mechanisms. Anyway, this approach is of methodological significance, but it can hardly be used in applied studies, in particular, in an analysis of regional development.
In regional sciences, including regional economy, main attention is focused on different factors of development that form the competitiveness of regions and localities. The institutional environment of those entities is not regarded as a development potential differing from other places in comparison with natural resources or advanced infrastructure.

\section{Institutions of income distribution}

The set of institutions related to economic growth and the corresponding increase in the level and quality of life in certain areas can be divided into three functional groups called distributive, transformational (reproductive) and organising ones (Fig. 1). The first group includes

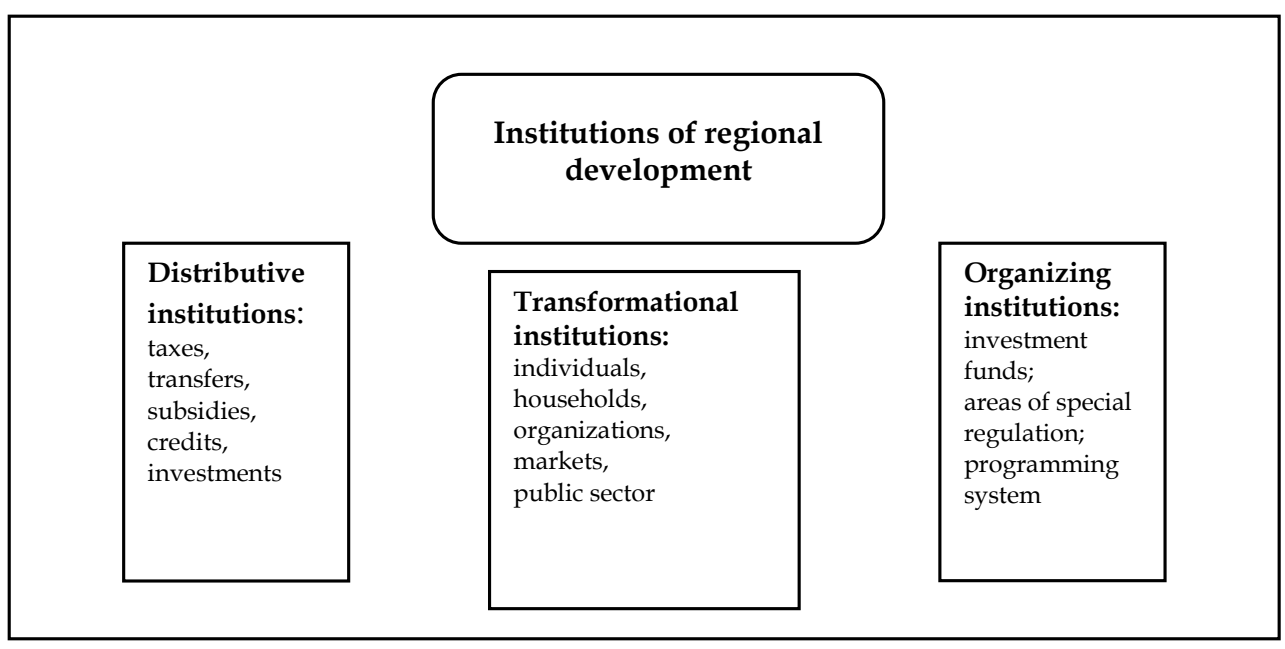

Fig. 1. Functional groups of development institutions

Source: author's own compilation 
institutions associated with the system of allocation of funds between the regions.

It is a common opinion that the cause of stagnation and depression in regions is the deficit of budget and investment. These questions are always a focus of public attention and are easily perceived as effective measures. The financial basis for regional development is formed by value added generated in the given area, household incomes, and rental payments for natural resources. All these sources of welfare have their own institutional problems. For example, due to the existing system of value added redistribution through taxes, local governments are left without the necessary funds. Municipalities are primarily responsible for economic growth and living conditions of their communities, but they depend on transfers from higher budgets and do not have their own funds for development. According to the Russian Audit Chamber, actual expenditures of local governments exceed their incomes twice and about $95 \%$ of municipalities have a deficit budget (Domnikov 2007).

Household incomes are usually not regarded as a stimulator of economic growth in a region. The overwhelming part of the population depends on wages. In the raw-material and primary processing economy characteristic of Russia, the main employers are raw-material monopolies and financial-industrial groups. There are no formal constraints for the ratio of higher- and lower-level staff wages, so a significant part of consumer income goes abroad or to the most prestigious areas in the country in order to maintain high standards of top managers' consumption.

Payments for natural resources, which are the basis of national wealth, make up less than $10 \%$ (in 2008, $6.4 \%$ ) of the region's consolidated budgets, and the rest goes to the federal budget (Finances of Russia 2008). There are various systems of withdrawal of natural rent, and the budgets of regions that are oil and gas suppliers are the richest, while regions with an abundance of wood resources have no adequate return.

The basic part of distributive institutions (taxes, transfers from special foundations) has a formal character and is regulated by laws, but all the regions are highly dependent on informal institutions. The principal one is the distribution of state investment into social facilities, infra- structure and various kinds of private business support within the framework of private-state partnership. The flow of investment into a region depends on the lobbying of its governor and deputies and on their political weight. That is why regions willingly invite members of the ruling elite to represent their interests officially in federal legislative and executive government bodies.

\section{Transformational institutions}

But an important object for studies of regional development should be the next group of institutions that transform income flows into the welfare of a regional community. This group of norms is more difficult to be perceived so it is seldom analysed at the regional or local levels. Transformational institutions do not fit the definition of geographical ones, as they are not determined by globality-locality relations (Stachowiak \& Stryjakiewicz 2008). They characterise the quality of a territorial community. If we assume that the national distribution system has changed in favour of the regions, an analysis of transformational institutions should answer two questions: a) whether the new funds will be invested in production or go to consumption, and b) what kind of production will be stimulated.

The institutional environment covers a wide range of notions and concepts. Formal and informal norms determine the economic behaviour of individuals, households, organisations, functioning of markets and the public sector. Most of such institutions have characteristics particular to the given area. The possibilities of developing an area depend on a combination of various factors affecting the subjects of regional and local economies. As to individuals, the motivation to work, the prestige of education and training, the desire to improve their social status are needed. These qualities are largely determined by informal relationships in local communities and the public position of local leaders.

Russia has experienced several stages of public sentiment for the post-soviet period. In the early years of transition, wide strata of the population were involved in entrepreneurial activity both for survival and for catching a chance to take 
up an advanced position in the new economy. Due to shortages of consumer goods and food it was prestigious to work on one's own land. But on the other hand the processes of population stratification and increasingly negative attitudes towards entrepreneurship intensified. Paternalistic sentiments returned to the society, confidence in the future declined. Labour began to give way to consumption in public priorities.

These two tendencies are found in different combinations, and are manifested in different ways. The active population concentrates in large cities, in other settlements elements of degradation tend to develop. In spite of unemployment it is difficult to recruit staff for production in some localities.

These processes have an impact on household institutions. Stereotypes of behaviour in the local systems help or hinder the organisation of family business, allow change of residence in the absence of work, determine the ability to concentrate resources on promoting potentially successful family members and on providing higher education for children. All this defines the quality of human capital as a factor of development in certain areas.

The impact of the institutions of organisation on regional development is determined primarily by the prevailing forms of production in the area that create the local investment climate. Investment can be put into new technologies, or into an expansion of the same resource exploitation according to the path dependence at the regional and local levels. In reality it is defined by the strongest player at a certain place, usually a raw-material or primary processing corporation. This kind of production is not a stimulator of innovation in an area, and it means the region suffers a gradual decline in the quality of human potential if efforts to develop other kinds of activity are not undertaken.

At this point it is necessary to mention the role of the state that contributes to the development of the institutional environment. In Russia, the state is a major player or a party to institutional relationships. Its functions in creating a favourable environment for economic activity development include stimulation or widening of initiative and motivation, protection of property rights, and protection of the freedom of economic activity.
The system of institutions in which the state participates should be formal by definition, i.e. be implemented in a legal form. The peculiarity of the Russian institutional system is the predominance of informal agreements in the state-society relationship. Compared with the uncertainty of the 1990s with their absence of institutions and the state, during the 2000s the government has swung toward so-called manual regulation, although it has been the most prosperous decade in modern Russian history. This kind of management was declared for the upper level of decisions in the economic sphere, but it had rapidly spread down to regional and local levels. In Russia, any project should be arranged with the appropriate level of authority, whether it is a transaction with a transnational corporation or opening a small shop. It suppresses entrepreneurial initiative and contradicts the concept of freedom of economic activities. Deficiency of formal norms of economic relations between the state and society leads not only to the absence of predictability, but also to the peculiar regional diversity of those relations.

An important consequence of manual regulation is the predominance of vertical relations over horizontal ones. The destruction of emerging horizontal communication and, accordingly, inhibition of the formation of new networks went under the slogan of a struggle against contrariness of regional and local leaders and elites. But the weakness of a regional elite means the weakness of middle-sized business and, accordingly, absence of accumulation of local investment capital and stagnation at the regional level of consumption.

Network research in Russian economic geography has received little attention. Network structures with horizontal connections consolidate a local community, form relationships without state participation in local systems, and create locally oriented economies. Regional patriotism is also a form of the institutional environment where the notion of embeddedness is transferred from the structural aspect into the cultural one.

A major economic consequence of this type of relationship between business and authorities is the strengthening of monopoly on regional and local markets, especially those of mass-demand goods. It is formed by informal preferences, artificial barriers, discrimination in the provision of 
public services, and other. The basis of the local economy is formed predominantly by infrastructure, the consumer environment, and the building complex. The state tries to struggle with monopoly in these sectors by developing a governmental programme to encourage competition at the local level (Programme ... 2009). The programme includes not only protective mechanisms in the form of antitrust laws, but also measures to promote competition, including tax policies, customs and tariff regulation, public procurement, and regulation of natural monopolies. For example, in the construction industry the state is going to transfer control over the quality of construction to so-called self-regulatory organisations which would represent professional associations. However, in the conditions of vertical power, associations of this type would also be dependent on the authorities, and programme activities can be carried out also formally.

\section{Organising institutions}

In the past few years the state has formulated a spatial strategy of regional development, including innovative one. The strategy introduced the concept of "development institutions", which include public and private investment funds, territorial zones with a special regime of state regulation, as well as a development programming system. These institutions have a formal nature and are designed to create a framework for state arrangements.

The state policy is set out in a principal document entitled the Concept of Improving Regional Policy in the Russian Federation. The Concept is aimed at reducing disparities in development among regions. The primary emphasis is put on a system of co-ordination of all levels of power - federal, regional and municipal. The principle of selective support that is usual for state development policy has been formalised in marking out so-called areas or zones of accelerated development. It is a new form of special areas in addition to territorial zones with a special regime of management. Special areas include free economic zones, industrial parks and other similar entities. Four types of free economic zones are established by law: technological, industrial, port, and tourist.
The principal element of the new strategy is an investment project to be supported by the state by means of joint financing or construction of physical infrastructure like roads, power supply, etc. A zone of accelerated development does not have any special features that distinguish it from the rest of the area, so it cannot be determined as a new institution.

The system of territorial programming includes a hierarchy of strategies and programmes of socio-economic development of regions and municipal units for long- and medium-term periods. The purpose of those programmes is to involve the available potential of areas in economic development and to increase living standards. Regions and municipalities are encouraged to look for new endogenous means and opportunities for growth. But those programmes do not address institutional problems and all the measures outlined in them must conform to the existing legal rules and regulations.

Similar programmes are written for some groups of regions. The largest one is the programme of social and economic development of Siberia. In late 2009 the strategy of the Far East and the Baikal region was approved by the government. Siberia has always been the main area for experiments with regional planning and now it is experiencing most serious problems with the implementation of new strategies.

A territorial production complex as a principal achievement of the Soviet spatial economy was worked out and implemented mainly in Siberian resource regions of low development. Those complexes gave appreciable results of economies of scale and other savings due to the combined use of land and infrastructure by interconnected enterprises. During the period of privatisation the key enterprises of the complexes were transferred to large financial-production groups and reoriented their sales from domestic to external markets. Despite their private status, they are the main objects of state planning just now.

The working out of a development programme for Siberia started in 2000 and was implemented by co-operation of the interregional association "Siberian Agreement", the Siberian Branch of the Academy of Sciences, the federal Ministry of Economic Development, and other organisations. It was the first strategy for a large 
macroregion. But during discussions in the federal government, there appeared fundamental disagreements among the sides engaged, posing a real threat to its official approval (Kuleshov 2007: 13-16). The disagreements included the following:

- the federal government representatives said that no changes could be introduced to federal legislation, although it contradicted the objectives of the programme aiming to reconcile regional and federal interests; and

- it was impossible to change a system of rental relations and institutional conditions offered by the working group.

As a result, a compromise version was adopted. But even this version was not implemented for a number of reasons, the main being the absence of an overall concept of the country's spatial development at that time and the predominance of the macroeconomic approach in economic regulation. A second version of the programme was created in 2005. It was based on an investment project as a key element and in fact anticipated the strategies that followed. A set of those projects has formed a belt of industrial development in the middle course of the Angara and Yenisey rivers called a zone of new industrialisation. A new hydroelectric power station Boguchany is planned as a heart of this belt producing energy for a new aluminium smelter and a pulp-and-paper mill. State participation is connected with the construction of roads and other infrastructure. The main beneficiary is the Basic Element Ltd (BASEL) corporation that possesses all aluminium plants in western Siberia and has shares in other large hydroelectric power stations there.

In times of a financial crisis the construction was stopped since the BASEL was a great debtor on external financial markets, but after a terrible breakdown at the largest Siberian hydroelectric power station, Sayano-Shushenskaya, the construction of Boguchany was forced by the government. Due to this crash the development programme of Siberia is also under revision now. It is a third variant based not only on investment projects but also on zones of accelerated development.

The history of this project shows the main drawbacks of the existing system of support for regional development. The authors of the devel- opment programme for Siberia offer the following measures to improve institutional conditions of its implementation (Kuleshov 2007: 31-49). First, a system of selection and justification of projects proposed for state support according to their social significance, availability of labour resources, and environmental safety. Secondly, a requirement for the basic projects to be supplemented by social and other programmes aimed at poverty reduction and development of alternative activities on the basis of small and mediumsize businesses. They also propose mechanisms for funding such programmes through changes in the system of income redistribution. Thirdly, much attention is paid to the organisation of management in developing areas where large projects are implemented. This system must reconcile the interests and co-ordinate the work of the three parties involved - business, the region, and the state, and control expenditures in the areas of project implementation.

These measures can only be effective when the fundamental principles of development management described above have changed. The problem is the institutional uncertainty of many basic mechanisms of such programmes, which in turn are related to the transformational institutions of regional development, both of an economic and spatial character. The lack of selection and justification of basic projects is due to their shortage. Moreover, they are based on outside investments of large corporations and come to the areas with prior approval. All the following expert reports, especially those assessing their social and environmental impact, have little influence on their content. Private-state partnership should formally set out the responsibilities of business and government to each other, which will contribute to the predictability of their behaviour. For example, the location of the free economic zone for tourism and recreation on the shores of Lake Baikal in the Irkutsk region has changed three times, and in all cases entrepreneurs have suffered due to lost investment. Also, the development of additional activities cannot be based on programme measures only, it should be encouraged by the protection of property rights, competition, and other aspects of the institutional environment. 


\section{Conclusions}

Regional development policy is being formed and launched in Russia. Concepts and programmes have been worked out and adopted for all regions and municipalities, as well as for the whole country and some macroregions. But the state does not change the essence of institutions affecting the development of regions. Regional science examines the institutions and institutional environment according to methodological principles that do not sufficiently reflect the real situation in the economies and communities of the various regions of the country. Real possibilities of territorial development meet with an inefficient system of regulation based on hierarchy, which reproduces the vertical nature of the relationships at all structural and territorial levels. This system is complemented by a large part of informal institutions in the business-authorities-society relations. Given the weakness of the judicial system, which has also been informally integrated into the executive power, it leads to corruption, monopolisation of power and markets of producers and consumers, increased transaction costs of business, and eventually to stagnation and depression in the regions. Regional investigations focus on the institutions of income distribution - the tax system, budgetary relations, and the distribution of public investment. However, the flow of money into a region is not enough for economic development. It is necessary that those funds should be invested in economic activity, not consumption. Regional sciences, including economic geography, should examine institutional factors of the transformation of income into investment as well as regional and local manifestations of legislative and informal norms that impede or facilitate the display of self-development with an active support of the state.

\section{References}

DOMNIKOv I., 2007. Budgetary paradoxes. Rossijskaya Gazeta. April, 5: 4.

Druzhinin A.G., Shuvalov V.E. (eds), 2004. Institutional modernisation of the Russian economy: The territorial aspect. MION, Rostov-na-Donu.

Finances of Russia, 2008. Statistical Yearbook. Rosstat, Moscow.

INSHAKOV O.V., FROLOv D.P., 2007. Institutionality of space in the concept of spatial economy. Spatial Economy 1: 5-17.

Kuleshov V.V. (ed.), 2007. Economy of Siberia at the beginning of the $21^{\text {st }}$ century. Rosstat, Moscow. IEIE, Novosibirsk.

MARTIN R., 2000. Institutional approaches in economic geography. In: Sheppard T., Barnes T.J. (eds.), A companion to economic geography. Blackwell, Oxford: 77-94.

Programme of the Development of Competition in the Russian Federation. Retrieved April 14 2010, from www.economy.gov.ru/minec/activity/sections/concuration/programconcur/

Russian Statistical Yearbook. 2008. Rosstat, Moscow.

STACHOWIAK R., STRYJAKIEWICZ T., 2008. Institutional approach in economic geography and its relevance to regional studies. Quaestiones Geographicae 27B/1: 7-20. 